\title{
TESTING TOOLS AND EVALUATION OF THE EFFICIENCY OF UAV PERSONNEL TRAINING ACCORDING TO KIRKPATRICK MODEL
}

\author{
NARZĘDZIA PROWADZENIA BADAŃ I OCENY \\ EFEKTYWNOŚCI SZKOLENIA PERSONELU \\ BEZZALOGOWYCH STATKÓW POWIETRZNYCH \\ WEDLUG MODELU KIRKPATRICKA
}

\author{
Wladysław Melnarowicz
}

Air Force Institute of Technology. Instytut Techniczny Wojsk Lotniczych

\begin{abstract}
An important field in the process of unmanned aerial vehicles operation $(U A V)$ is the system of training operators and technicians. The article presents methods for measuring and evaluating the effectiveness of training systems using the Kirkpatrick model. This model has been used in the study of the flight crew training system and presents the possibility of its use in the training of unmanned aircraft personnel. The study presents tools and methodology for measuring training effects at individual levels of the Kirkpatrick model.
\end{abstract}

Keywords: training effectiveness, Kirkpatrick model, unmanned aerial vehicles $(U A V)$

Streszczenie: Ważnym obszarem w procesie eksploatacji bezzałogowych statków powietrznych (BSP) jest system szkolenia operatorów i techników. W artykule przedstawiono metody pomiaru i oceny efektywności systemów szkoleniowych za pomoca modelu Kirkpatricka. Model ten autor stosowat $w$ badaniach systemu szkolenia personelu lotniczego $i$ prezentuje możliwość jego zastosowania wszkoleniu personelu bezzalogowych statków powietrznych. W opracowaniu przedstawiono narzędzia $i$ metodyke pomiaru efektów szkoleniowych na poszczególnych poziomach modelu Kirkpatricka.

Stowa kluczowe: efektywność szkolenia, model Kirkpatricka, bezzałogowy statek powietrzny (BSP). 
Narzędzia prowadzenia badań i oceny efektywności szkolenia personelu...

Testing tools and evaluation of the efficiency of uav personnel training according...

\section{Wstęp}

Określenie celów i zadań zawodowych stanowi punkt odniesienia w tworzeniu miar oceny efektywności. W szkoleniu personelu bezzałogowych statków powietrznych (BSP), pomiar efektywności powinien mieć aspekt finansowy ale musi uwzględniać również inne elementy, takie jak: bezpieczeństwo lotów, otoczenie systemowe, praca $w$ warunkach silnego stresu itp. Stworzenie uniwersalnych wskaźników służących kompleksowej ocenie efektywności jest trudne, dlatego każda organizacja szkoleniowa, indywidualnie w zależności od potrzeb i wymagań licencyjnych, powinna sprecyzować narzędzia i kryteria pomiaru i oceny efektywności, tak jak samodzielnie określa i hierarchizuje cele szkolenia.

Spośród wielu modeli stworzonych do badania i oceny systemów szkolenia, największe zastosowanie $\mathrm{w}$ dziedzinie szkolenia zawodowego zyskał Model Kirkpatricka [2001]. Cecha charakterystyczną tego modelu są cztery poziomy, na których badane i oceniane są efekty szkoleniowe. Są to: poziom reakcji, nauki, zachowań i rezultatów. Wszystkie etapy mają określone funkcje i muszą następować kolejno po sobie. Za pomocą tego modelu autor prowadził badania w systemie szkolenia personelu lotniczego i proponuje zastosowanie go w szkoleniu operatorów i techników bezzałogowych statków powietrznych.

\section{Model Kirkpatricka}

Model Kirkpatricka opracowany został w latach sześćdziesiątych XX wieku i jest najbardziej rozpowszechnionym miernikiem efektywności szkoleń. Wszystkie opracowane później modele: Hamblina [1994], Phillipsa [2000], Brinkerhoffa [2003] i inne, opierają się w dużej części na modelu Kirkpatricka i zawierają rozszerzenia związane $\mathrm{z}$ prowadzeniem badań efektywności szkolenia w specyficznych dziedzinach.

Szkolenia muszą przynosić szeroko rozumiane zyski. Jak sprawdzić, czy szkolenie przyniosło zamierzone efekty? A nawet, czym właściwie są te zamierzone efekty?

Efektywność szkolenia badana jest na czterech poziomach (rys.1.), które określił D.L. Kirkpatrick:

- poziom reakcji;

- poziom nauczania;

- poziom zachowania;

- poziom rezultatów.

Pierwszym $\mathrm{z}$ nich jest (1) reakcja uczestników. Zazwyczaj jest to ocena pozytywna, dlatego, że mieli szansę oderwać się od szarej rutyny, zintegrować ze współpracownikami, usłyszeć o nowych urządzeniach i technologiach, poczuć, że pracodawca dba o ich rozwój i być może planuje awans zawodowy. Choć wymienione powody mogą się wydawać trywialne i nieistotne z punktu widzenia firmy, nie należy ich ignorować, bo zadowolony i zmotywowany pracownik to pierwszy krok do zwiększenia jakości i wydajności pracy. 


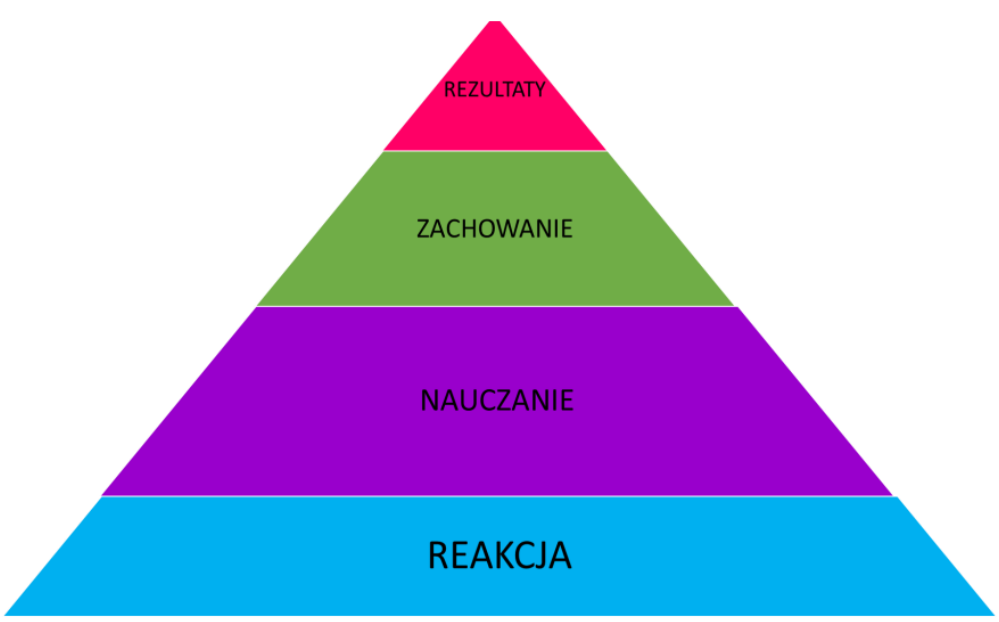

Rys. 1 Model Kirkpatricka

Kolejny poziom to (2) poziom nauczania. Tutaj przeprowadza się przykładowo testy wiedzy i umiejętności lub używa się innych technik umożliwiających sprawdzenie poziomu osiągnięcia celów dydaktycznych. Celem szkolenia jest również (3) zmiana postaw. Trudno zmierzyć tę wartość za pomocą testu. Dużo skuteczniejsze jest tutaj wykorzystanie kolejnego etapu badania skuteczności, jakim jest element badania zmian w zachowaniu. Ostatni etap, najbardziej oddający skuteczność szkolenia, jest też najtrudniejszy. Chodzi o (4) badanie rezultatów na poziomie organizacji. Na tym poziomie chcemy wiedzieć, jakie wymierne korzyści przyniosło szkolenie. Jest kilka metod, by to sprawdzić (zwrot z inwestycji ROI, arkusz inwestycji i korzyści, analiza kosztów i korzyści na grupie kontrolnej). Nie ulega jednak wątpliwości, że są to żmudne kalkulacje i że nie ma stuprocentowej skuteczności przeprowadzonej analizy. Dzieje się tak dlatego, że kontrola innych czynników również wpływających na efektywność jest utrudniona. Dlatego najskuteczniejsza z dostępnych metod jest analiza kosztów i korzyści na grupie kontrolnej. W metodzie tej porównujemy wyniki pracowników, którzy przeszli szkolenie oraz takich, którzy nie skorzystali z tej możliwości.

A jak badanie efektywności wygląda w firmach delegujących pracowników na szkolenie? Niestety jest niewielu pracodawców, którzy pragną poznać i oceniać efekty szkolenia swoich pracowników. Dużym problemem jest uzyskanie wypełnionych ankiet dostarczonych przez organizację szkoleniową do firmy kierującej pracowników na szkolenie.

\section{Prowadzenie badań efektywności szkolenia za pomocą Modelu Kirkpatricka}

Skuteczne prowadzenie badań w systemie szkolenia wymusza odpowiednią konstrukcję programu nauczania umożliwiającą prowadzenie oceny szkolenia. Wymierna ocena efektywności wymaga starannego zaprogramowania systemu szkolenia i wyboru odpowiednich kryteriów oceny. 
Narzędzia prowadzenia badań i oceny efektywności szkolenia personelu... Testing tools and evaluation of the efficiency of uav personnel training according...

W tym celu konieczna jest taka forma programu nauczania, która zawiera operacyjne cele szkolenia. Ocena efektywności szkolenia jest ułatwiona, jeżeli program nauczania jest opracowany w technologii MES (Module of Employable Skills). Programy takie noszą nazwę programów modułowych, w których specyfika czynności wykonywanych $\mathrm{w}$ ramach pracy wyrażana jest w programie nauczania w postaci modułów i jednostek modułowych. Konstrukcję takich programów, do szkolenia personelu bezzałogowych statków powietrznych, autor przedstawił w książce: Ocena efektywności szkolenia personelu BSP.

\section{Poziom reakcji}

Poziom reakcji, to szeroko rozumiana reakcja pracowników na szkolenie. Zbiera się na nim subiektywne wrażenia, opinie i oceny stopnia zadowolenia uczestników szkolenia na temat treści, metod organizacji szkolenia oraz warunków, w których odbywa się szkolenie. Na tym poziomie zbiera się także informacje o możliwości zastosowania zdobytej podczas trwania szkolenia wiedzy i umiejętności na stanowisku pracy. W modelu D. L. Kirkpatricka często nazywa się to „pomiarem zadowolenia klienta".

Pomiaru dokonuje się najczęściej za pomocą kwestionariusza ocen lub ankiety wypełnianej przez uczestników po zakończeniu szkolenia. Zaleca się stosowanie skali punktowej, wariantu wyboru oraz pytań otwartych. Przykładem tego typu ankiety jest ankieta oceny poziomu reakcji stosowana bardzo często przez autora opracowania (Melnarowicz, 2018) na zakończenie kursów szkolenia zawodowego.

\section{Poziom nauczania}

Poziom nauczania, to badanie za pomocą testów i sprawdzianów stopnia osiągnięcia celów dydaktycznych szkolenia. Analiza na tym poziomie ma na celu ustalenie rzeczywistego przyrostu wiedzy i umiejętności $\Delta \mathrm{W}$ (zal.1). Do przeprowadzenia takiej analizy niezbędna jest ocena umiejętności wejściowych i końcowa ocena wyników nauczania.

Pomiaru umiejętności wejściowych dokonuje się z dwu powodów. Po pierwsze, pozwala to na weryfikację założeń programowych projektowanego systemu. System szkolenia ma umożliwić uczniom zdobycie kolejnych wyższych poziomów wiedzy i umiejętności. Konstruując system należy wiedzieć jaką wiedzę i umiejętności posiadają kandydaci do szkolenia. Drugim powodem mierzenia wejściowych parametrów wiedzy i umiejętności jest uzyskanie w ten sposób podstawy porównawczej pozwalającej na ustalenie stopnia przyrostu wiedzy i umiejętności.

Jeżeli na koniec kursu wykładowca stwierdza, że jego słuchacze nie osiągnęli operacyjnych celów końcowych, to informacja o ich umiejętnościach wejściowych pomaga mu rozstrzygnąć czy odpowiedzialnością za taki stan rzeczy należy obarczać nieskuteczność nauczania, czy małe umiejętności wejściowe uczniów. Oceny otrzymane przez uczniów na świadectwach szkolnych czy rodzaj ukończonej szkoły nie stanowi dobrej miary wiedzy i umiejętności wejściowych. 
Zachodzi zatem potrzeba przygotowania i przeprowadzenia testu wiedzy i umiejętności wejściowych, aby mieć pewność, że na nich można bazować w realizacji nowego kursu szkoleniowego. Podobne metody stosowane są w bieżącej realizacji materiału programowego. Jeżeli nauczyciel przekona się, że jego uczniowie nie mają niezbędnej wiedzy i umiejętności wejściowych i nie zmieni swojego planu nauczania naraża się na ryzyko, że wielu słuchaczom nie uda się osiągnąc końcowych celów szkolenia.

Jeżeli test umiejętności wejściowych wykazuje, że większość szkolonych nie ma wystarczającej wiedzy i umiejętności do kontynuacji szkolenia, możliwe są następujące działania:

- jeżeli z dokumentów wynika, że wiedza i umiejętności zostały uprzednio wyuczone i zapomniane, można przed rozpoczęciem szkolenia przeprowadzić powtórzenie materiału,

- jeżeli nic nie wskazuje, by uczniowie kiedykolwiek spotkali się z wymaganą problematyką, można przygotować i przeprowadzić specjalną jednostkę dydaktyczną,

- jeżeli nie dysponuje się dostateczną ilością czasu i żadna z powyższych możliwości nie wchodzi $\mathrm{w}$ grę, można $\mathrm{w}$ porozumieniu ze zleceniodawcą ograniczyć liczbę celów końcowych lub zrezygnować np. $\mathrm{z}$ modułów rozszerzenia,

$\mathrm{O}$ ile żadna $\mathrm{z}$ tych możliwości nie jest dostępna bo cele wynikają z przepisów odgórnych np. wymagań do licencji, do rozpoczęcia kursu mogą być dopuszczeni jedynie uczniowie, którzy osiągnęli cele wejściowe. Taki kompetencyjny czy mistrzowski system szkolenia (mastery learning) jest stosowany w szkoleniu personelu lotniczego i nauczaniu języków obcych.

Test wiedzy i umiejętności wejściowych stosowany przed rozpoczęciem szkolenia pozwala na obliczanie poziomu wiedzy przed szkoleniem Tp niezbędnej do przeprowadzenia obliczeń wskaźnika przyrostu wiedzy i umiejętności $\Delta \mathrm{W}$ (1) oraz analizy i oceny efektywności szkolenia. Przeprowadzenie testów kompetencji przed i po szkoleniu służy uzyskaniu rzetelnej oceny wiedzy, umiejętności i postaw przyswojonych i ugruntowanych przez uczestników w trakcie szkolenia. Bez przyswajania nowej wiedzy i umiejętności nie jest możliwa korekta zachowania i rozpatrywanie zmian na poziomie trzecim. Właściwy dobór metodyki badań i kryteriów oceny szkolenia na poziomie drugim warunkuje poprawność i wiarygodność całego procesu oceny efektywności szkolenia.

Koncepcja opracowania modułowych programów nauczania zawiera operacyjne cele szkolenia które są jednocześnie pytaniami do testów końcowych, ponieważ określają:

- zachowanie końcowe,

- warunki jego przejawiania,

- standardy osiągania zachowania końcowego.

Mając wyniki testu początkowego i końcowego oraz ustalone kryterium akceptacji przystępuje się do obliczenia przyrostu wiedzy i umiejętności. 
Narzędzia prowadzenia badań i oceny efektywności szkolenia personelu...

Testing tools and evaluation of the efficiency of uav personnel training according...

\section{Obliczanie wskaźnika przyrostu wiedzy i umiejętności $\Delta \mathbf{W}$}

Po przeprowadzeniu i sprawdzeniu testu końcowego należy obliczyć wskaźnik przyrostu wiedzy i umiejętności $\Delta \mathrm{W}$.

gdzie:

$$
\Delta \mathrm{W}=\frac{(\text { Tk-Tp })}{(\text { Tmax-Tp })} \times 100 \%
$$

$\mathrm{T}_{\mathrm{k}}$ - wynik testu końcowego ( po szkoleniu),

$\mathrm{T}_{\mathrm{p}}$ - wynik testu początkowego ( przed szkoleniem ),

$\mathrm{T}_{\max }-$ max. wynik testu ( $100 \%$ odpowiedzi poprawnych ).

\section{Przykład:}

Test końcowy zawiera 30 pytań, a poziom akceptacji to poprawne rozwiązanie min. $60 \%$ zadań testowych - czyli 18 zadań. Przed szkoleniem uczeń nie rozwiązał poprawnie 10 zadań, a po szkoleniu rozwiązał poprawnie 25 zadań. Oblicz minimalny wskaźnik przyrostu wiedzy i umiejętności $\Delta \mathrm{Wmin}$ i wskaźnik $\Delta \mathrm{Wn}$ uzyskany przez ucznia po zakończeniu szkolenia:

$$
\begin{gathered}
\Delta \mathrm{Wmin}=\frac{18-10}{30-10} \times 100 \%=40 \% \\
\Delta \mathrm{Wn}=\frac{25-10}{30-10} \times 100 \%=75 \%
\end{gathered}
$$

Zbiorcze wyniki egzaminu końcowego wymagają opracowania statystycznego w celu dokonania analizy i oceny osiągniętych wyników nauczania w grupach i turnusach szkoleniowych oraz wykorzystania ich do doskonalenia systemu szkolenia.

Bardzo rzadko rozkład przyrostu wiedzy i umiejętności ma charakter rozkładu normalnego. W wielu przypadkach, zwłaszcza przy testowaniu przyrostu wiedzy (po aproksymacji wykresu), uzyskuje się rozkład zbliżony do rozkładu normalnego.

Rozkład symetryczny normalny - jest obrazem idealnego losowego rozkładu wyników. W rozkładzie normalnym średnia arytmetyczna, modalna i mediana sa sobie równe, $\Delta \mathrm{W} s ́ r=\mathrm{Me}=\mathrm{Mo} \mathrm{i} \mathrm{w}$ punkcie tym wyniki osiągają określoną wartość maksymalną. Rozkład tego typu przedstawia rys. 2, n [liczność uczniów osiągająca przyrost $\Delta \mathrm{W}]$.

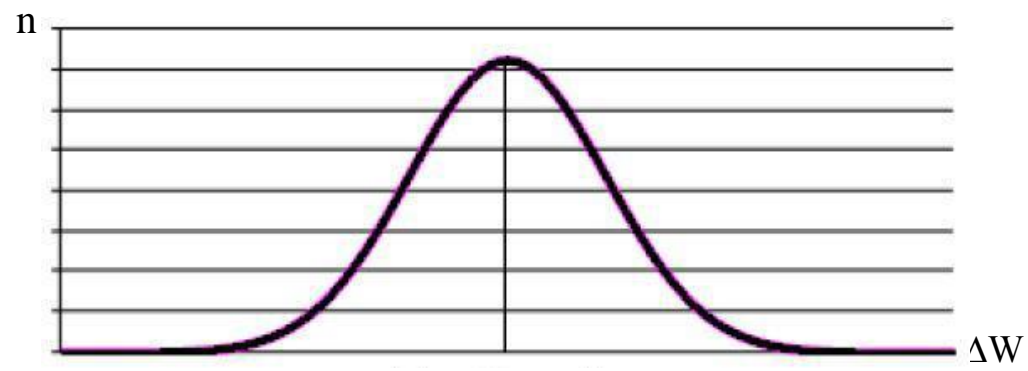

$$
\Delta \mathrm{W} s \dot{r}=\mathrm{Me}=\mathrm{Mo}
$$

Rys. 2 Rozkład normalny przyrostu wiedzy i umiejętności $\Delta \mathrm{W}$ 
Rozkład asymetryczny prawostronny (prawostronnie, dodatnio skośny) - rozkład wyników przesunięty jest w lewo w kierunku niskich wartości. Modalna i mediana tego rozkładu są mniejsze od wyniku średniego, $\mathrm{Mo}<\mathrm{Me}<\Delta$ Wśr. Rozkład ten jest charakterystyczny w testach trudnych dla zdających. Wykres rozkładu przyrostu wiedzy i umiejętności dla tego przypadku przedstawia rys. 3 .

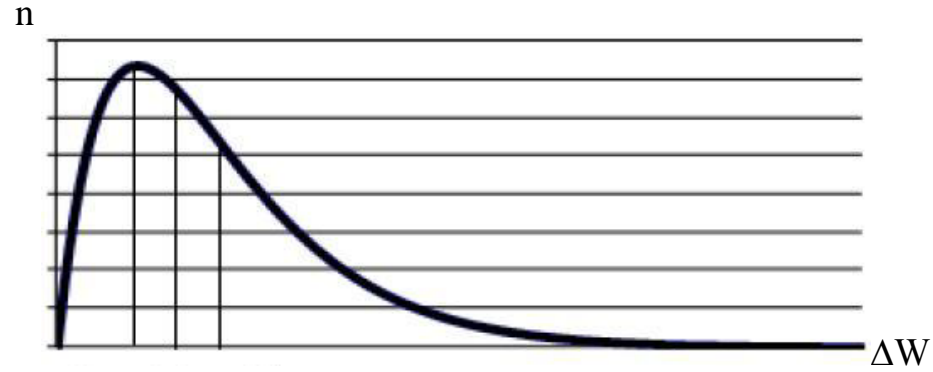

Mo Me $\Delta$ Wśr

Rys. 3 Rozkład prawostronny niesymetryczny przyrostu wiedzy i umiejętności $\Delta \mathrm{W}$.

$$
\text { Mo }<\text { Me }<\Delta \text { Wśr }
$$

Rozkład asymetryczny lewostronny (lewostronnie, ujemnie skośny) - rozkład wyników przesunięty jest w prawo w kierunku wysokich wyników. Modalna i mediana tego rozkładu są większe od wyniku średniego, $\Delta$ Wśr $<$ Me $<$ Mo. Rozkład ten jest charakterystyczny w testach łatwych i przedstawiony jest na rys. 4 . W zdecydowanej większości przypadków, podczas badania przyrostu wiedzy i umiejętności w systemie szkolenia personelu lotniczego, pojawiał się rozkład lewostronny dla testów umiejętności praktycznych (rys. 5) oraz normalny i prawostronny dla testów wiedzy użytecznej, co jest charakterystyczne dla testów o większym stopniu trudności.

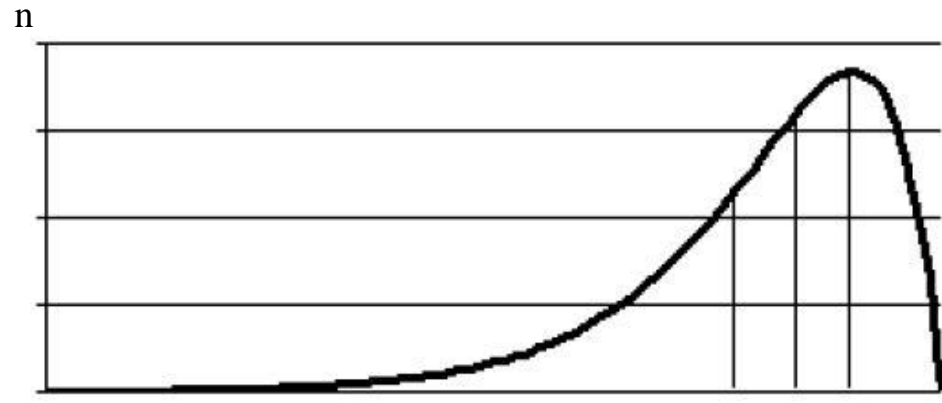

$\Delta$ Wśr Me Mo

Rys. 4 Rozkład asymetryczny lewostronny przyrostu wiedzy i umiejętności $\Delta \mathrm{W}$ 
Narzędzia prowadzenia badań i oceny efektywności szkolenia personelu...

Testing tools and evaluation of the efficiency of uav personnel training according...

\section{Opracowanie i analiza wyników pomiaru wskaźnika przyrostu wiedzy i umiejętności}

Sporządzenie graficznego rozkładu wyników $\Delta \mathrm{W}$ (histogramu) z testu końcowego wykonuje się za pomocą metod statystycznych. Wyniki obliczeń $\Delta \mathrm{W}$ dla grupy szkoleniowej o liczbie uczniów $\mathrm{N}=30$ przedstawione są w tabeli 1 . oraz graficznie (rys. 5).

Oś pozioma to procentowy przyrost $\Delta \mathrm{W}$, który można otrzymać na podstawie wyników testu (od zera do 100\%), a oś pionowa to liczność grupy uczniów (n), którzy przystąpili do testu końcowego i uzyskali obliczony według wzoru (1) wskaźnik przyrostu wiedzy i umiejętności.

Tab. 1 Zestawienie wyników testu końcowego

\begin{tabular}{|c|c|c|c|c|c|c|c|c|c|}
\hline$\Delta \mathrm{W}[\%]$ & 20 & 30 & 40 & 50 & 65 & 75 & 85 & 90 & 100 \\
\hline $\begin{array}{c}\text { n [liczba } \\
\text { uczniów] }\end{array}$ & 1 & 3 & 5 & 6 & 7 & 5 & 2 & 1 & 0 \\
\hline
\end{tabular}

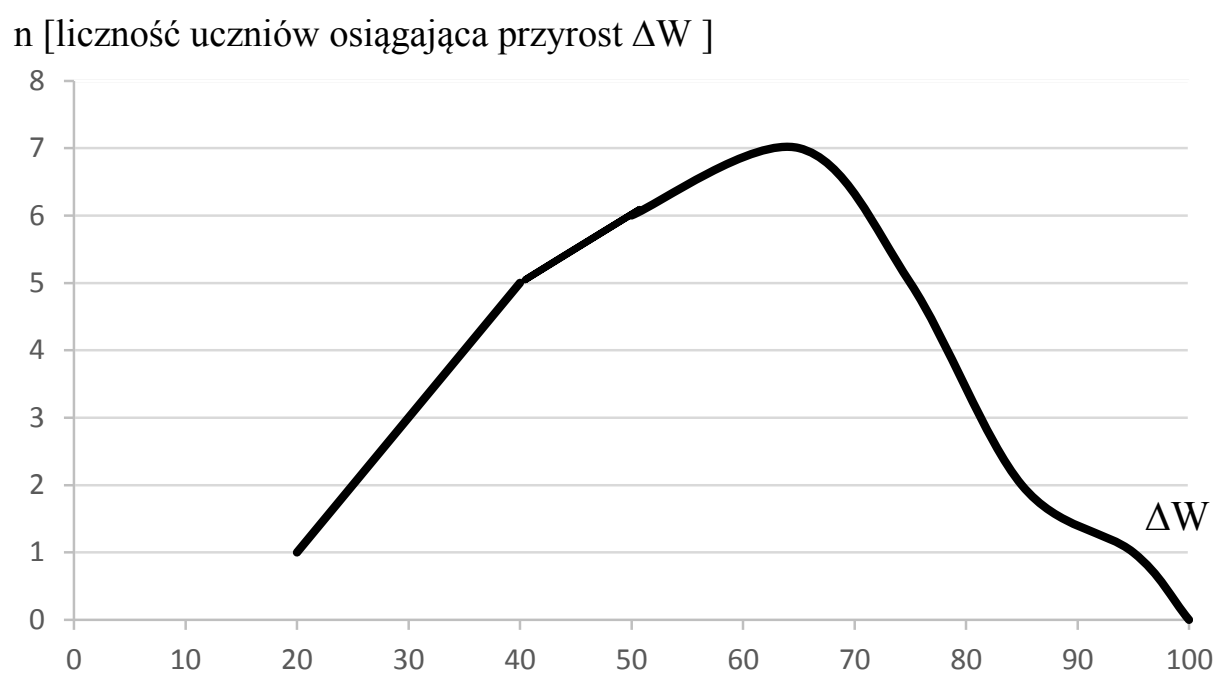

Rys. 5 Graficzny rozkład przyrostu umiejętności $\Delta W$

( asymetria lewostronna)

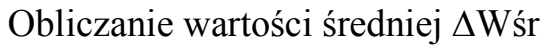

$$
\Delta W_{\text {śr }}=\frac{\sum_{i=1}^{N} \Delta W_{i}}{N}
$$

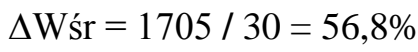


Modalna (dominanta) Mo $=65 \%$, to oznacza, że największa liczba uczniów ( $\mathrm{n}=7$ ) uzyskała przyrost wiedzy i umiejętności o $65 \%$.

Rozstęp R

$$
\mathrm{R}=95-20=75 \%
$$

Wariancja $\delta^{2}$

$$
\begin{gathered}
\delta^{2}=\frac{\sum_{i-1}^{N}\left(\Delta W_{i}-\Delta W_{s r}\right)^{2}}{N} \\
\delta^{2}=10374,20 / 30=345,81
\end{gathered}
$$

Odchylenie standardowe $\delta$ - jest to miara zmienności $\Delta \mathrm{W}$ wewnątrz grupy, jest to informacja ile wyników znajduje się w przedziale $[-\delta,+\delta]$

$$
\delta=\sqrt{\delta^{2}}=18,6
$$

To oznacza z prawdopodobieństwem $62,28 \%$, że wyniki przeprowadzonych testów

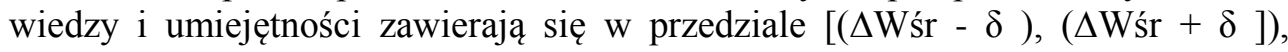
a więc przyrost wiedzy i umiejętności mieści się w przedziale 38,2\% -75,4\%.

Mediana Me jest obok średniej arytmetycznej najczęściej stosowanym parametrem statystycznym. Aby obliczyć medianę w zbiorze uczniów objętych testem sortujemy wyniki od najmniejszego do największego przyrostu $\Delta \mathrm{W}$. Jeżeli liczba uczniów N poddana testowi jest liczbą nieparzystą wartość mediany leży dokładnie pośrodku zbioru. Jeżeli $\mathrm{N}$ jest liczbą parzystą tak jak w rozpatrywanym przypadku, wówczas wynik jest średnią arytmetyczną pomiędzy dwiema środkowymi obserwacjami N/2 i N/2+1.

$\mathrm{W}$ rozpatrywanym przypadku mediana wynosi:

$$
\mathrm{Me}=(65+50) / 2=57,5 \%
$$

Rozkład przyrostu wiedzy i umiejętności $\Delta \mathrm{W}$, rzadko ma charakter rozkładu normalnego, w którym wartości średniej arytmetycznej, modalnej i mediany pokrywają się. W przypadku rozkładu normalnego (Gausa) spełniony jest warunek:

$$
\Delta \mathrm{W} s \dot{r}=\mathrm{Me}=\mathrm{Mo}
$$

W badaniach prowadzonych przez autora w systemie szkolenia personelu lotniczego, najczęściej pojawiały się rozkłady prawoskrętne i lewoskrętne. Im większe są różnice między średnią arytmetyczną a modalną, tym bardziej asymetryczny jest rozkład cechy $\Delta \mathrm{W}$.

Jeżeli spełniona jest nierówność $\Delta \mathrm{W}$ śr $>\mathrm{Me}>\mathrm{Mo}$, to mówimy $\mathrm{o}$ asymetrii prawostronnej (rys.3), a gdy $\Delta \mathrm{W} s ́ r<\mathrm{Me}<\mathrm{Mo}$ - jest to asymetria lewostronna (rys.4).

W testach wiedzy pojawiają się często rozkłady prawostronne, a w testach umiejętności rozkłady o asymetrii lewostronnej, co oznacza, że testy umiejętności przysparzają lotnikom mniej problemów. 
Narzędzia prowadzenia badań i oceny efektywności szkolenia personelu... Testing tools and evaluation of the efficiency of uav personnel training according...

Otrzymane rezultaty wynikają również z faktu, że wykładowcy i instruktorzy kładą szczególny akcent $\mathrm{w}$ procesie szkolenia na bezpieczeństwo lotów, a skuteczne praktyczne nauczanie procedur technicznych i operacyjnych o tym w głównej mierze decydują.

Oprócz testu wiedzy i umiejętności, na poziomie drugim stosowane są również inne techniki pomiaru, zależnie od specyfiki szkolenia i poziomu szkolonych.

W szkoleniu personelu technicznego często stosuje się obserwację wykonywanej przez ucznia procedury technologicznej przy zachowaniu warunków BHP i wykorzystaniu właściwych narzędzi i aparatury kontrolno-pomiarowej. W szkoleniu operatorów bezzałogowych statków powietrznych, może to być poprawne wykonanie startu i lądowania, identyfikacja celu lub inne praktyczne zadanie. W przypadku szkolenia organizatorów systemów, uzupełnieniem testów wiedzy i umiejętności mogą być stosowane case study (studium przypadków), $\mathrm{w}$ trakcie i na zakończenie szkolenia.

Badania związane $\mathrm{z}$ oceną efektywności szkolenia prowadzone na pierwszym i drugim poziomie modelu D.L. Kirkpatricka, realizuje się w systemie szkolenia, obojętnie czy szkolenie realizowane jest w siedzibie firmy szkoleniowej, czy w siedzibie zlecającego. Pozostałe badania na poziomie zachowania i rezultatów prowadzone są na stanowiskach pracy przy udziale podmiotu zlecającego szkolenie i ponoszącego koszty szkolenia traktując je jako inwestycje, mające przynieść firmie zwrot $\mathrm{z}$ inwestycji ROI (return on investment).

\section{Poziom zachowania}

Poziom zachowania, to obserwowanie pozytywnych zmian $\mathrm{w}$ zachowaniu uczestników szkolenia po zakończeniu kursu. Na tym poziomie określa się, w jakim stopniu modyfikacja zachowań na stanowisku pracy jest efektem uczestnictwa w kursie szkoleniowym. Jeżeli nie pojawią się pozytywne zmiany, będące skutkiem zabiegów szkoleniowych, nie można oczekiwać wzrostu efektywności działania. Zatem, analiza na tym poziomie pokazuje, czy i w jakim stopniu wiedza i umiejętności nabyte podczas szkolenia są stosowane praktycznie w miejscu pracy. Elementami podlegającymi ocenie mogą być: jakość pracy, wzrost wydajności pracy, lepsze wykorzystanie czasu pracy, lepsza współpraca w zespole $\mathrm{i}$ radzenie sobie $\mathrm{z}$ konfliktami, poprawa umiejętności interdyscyplinarnych i interpersonalnych itp. W celu zmierzenia tych elementów wykorzystuje się wskaźniki wymierne oraz opinie współpracowników i przełożonych oparte na rozmowach i obserwacji. Prowadzenie oceny na poziomie zachowania niesie w sobie duże prawdopodobieństwo subiektywizmu i zazwyczaj analizy i oceny tego poziomu wymagają potwierdzenia w etapie kolejnym na poziomie rezultatów.

\section{Poziom rezultatów}

Poziom rezultatów, to badanie i określanie trwałych rezultatów szkolenia widocznych $\mathrm{w}$ wynikach funkcjonowania całej organizacji po upływie kilku miesięcy od zakończenia szkolenia. 
Na tym etapie poszukuje się danych potwierdzających ekonomiczną efektywność szkolenia w postaci mierników obrazujących np. wzrost produkcji, wydajności pracy, spadek absencji, zmniejszenie fluktuacji, redukcję kosztów itp. Nie wszystkie wyniki muszą być odzwierciedlane w postaci mierników finansowych. Powinno się oszacować również inne czynniki, które w dłuższym czasie spowodują wzrost wskaźników wymiernych.

Podstawowa trudność pomiaru rezultatów na tym poziomie polega na wyeliminowaniu wpływu czynników niezwiązanych z procesem szkoleniowym, a mogących oddziaływać na wyniki działalności firmy czy instytucji. Stąd ocena na tym etapie wymaga wielu drobiazgowych pomiarów statystycznych, analizy wyników badań na poziomie drugim i pogodzenia się z koniecznością pewnych przybliżeń.

Podstawowymi narzędziami oceny efektywności szkolenia na poziomie korzyści długoterminowych są: Ankiety, Wskaźnik ROI oraz Arkusz inwestycji i korzyści.

Zwrot $\mathbf{z}$ inwestycji ROI (return on investment) informuje, ile procent zysku $\mathrm{z}$ zainwestowanej w szkolenie kwoty osiągnęła firma w określonym czasie.

Kiedy potrzeba twardych danych finansowych uzasadniających poniesione koszty szkolenia model D. Kirkpatricka okazuje się niewystarczający. Należy zastosować wówczas zaproponowany przez J. Philipsa wskaźnik ROI:

$$
\mathrm{ROI}=\frac{\mathrm{Zn}}{\mathrm{K}} \times 100
$$

gdzie :

$\mathrm{Zn}$ - zysk netto

$\mathrm{K}$ - kapitał (koszty inwestycji)

Zastosowanie wskaźnika ROI do pomiaru efektywności szkolenia jest możliwe tylko w przypadku odpowiedniego zaprojektowania całego procesu szkoleniowego, zwłaszcza precyzyjnego określenia operacyjnych celów szkolenia, tak aby możliwy był ich dokładny pomiar. Jest to bardzo ważne, ponieważ nakłady poniesione na dogłębną ewaluację programu szkoleniowego mogą uchronić firmę przed dużo większymi stratami wynikającymi $\mathrm{z}$ nieskutecznych projektów rozwojowych. Dlatego też na początku ustala się związki przyczynowe pomiędzy brakiem wiedzy i umiejętności pracowników a konkretnymi problemami, które zostały zidentyfikowane i są przyczyną strat wyrażonych w konkretnej kwocie pieniężnej i jakości, gdy problem nie był rozwiązany. Następnie po przeprowadzeniu szkolenia mierzy się efektywność procesu przez porównanie zakładanych korzyści z nakładami poniesionymi na szkolenie. 
Narzędzia prowadzenia badań i oceny efektywności szkolenia personelu...

Testing tools and evaluation of the efficiency of uav personnel training according...

Arkusz inwestycji i korzyści, to narzędzie, które zestawia wszelkiego rodzaju koszty poniesione na szkolenie zarówno wymienne jak również te niewymierne które należy oszacować i przypisać im wagi wyrażone w pieniądzu.

Koszty wymierne poniesione na szkolenie to koszty opracowania programu, uczestnictwa w szkoleniu, materiałów szkoleniowych, dojazdu (hotelu), nieobecności w miejscu prac, itp.

Koszty niewymierne, które należy oszacować to wyższa produkcja, lepsza jakość, oszczędność czasu, spadek absencji, poprawa bezpieczeństwa itp.

Prowadzone przez autora badania efektywności szkoleń dowodzą jednoznacznie, że ostatni poziom oceny sprawia delegującym na szkolenia największe trudności. Jedną z przyczyn takiego stanu rzeczy jest fakt, że zamawiający szkolenia i firma szkoleniowa nie potrafią jednoznacznie zdefiniować swoich ról i potrzeb oraz jednoznacznie określić operacyjnych celów szkolenia. Firmy zamawiające szkolenia pobieżnie traktują etap diagnozy potrzeb szkoleniowych i opracowania szczegółowych celów w oparciu o oczekiwany przyrost kwalifikacji po zakończeniu szkolenia.

W badaniach przeprowadzonych przez Katedrę Zarządzania Produkcją i Pracą Akademii Ekonomicznej we Wrocławiu [2010], 1/3 respondentów uznała, że nie wie czy ktoś w zakładzie zajmuje się problemem oceny efektywności szkolenia, a $25 \%$ przedsiębiorstw stwierdziło wprost, że nie prowadzi oceny efektywności szkoleń.

Firmy realizujące szkolenia koncentrują się na przekazywaniu wiedzy i jej pomiarze w trakcie i po zakończeniu szkolenia (poziom pierwszy i drugi) i nie interesują się trwałymi rezultatami szkolenia, które powinny być widoczne w wynikach funkcjonowania organizacji kierującej pracowników na szkolenie.

Taka sytuacja uniemożliwia przeprowadzenie pełnej analizy i oceny efektywności szkolenia według modelu Kirkpatricka i jest najczęściej popełnianym błędem przez organizacje szkoleniowe i firmy zlecające szkolenie i doszkalanie pracowników.

\section{Podsumowanie}

Pomiar efektywności działania jest jedną z najbardziej dynamicznie rozwijających się dziedzin ostatnich lat. Obiektem szczególnego zainteresowania stały się również systemy szkolenia personelu lotniczego, w których możliwy jest skuteczny pomiar i wymierna ocena efektywności. Autor artykułu opracował model organizacji szkolenia operatorów i techników BSP oraz przedstawił narzędzia, które ten pomiar umożliwią.

Obliczenia poziomu nauczania i jej formy graficzne to jedynie prognoza tego, że osiągnęliśmy w mniejszym lub większym stopniu zadowalający przyrost wiedzy i umiejętności. 
Rzeczywisty przyrost kwalifikacji można jednak ocenić dopiero wówczas gdy porównamy uzyskane wyniki z wynikami badań przeprowadzonych na poziomie trzecim i czwartym z wynikami osiąganymi na zakończenie szkolenia. Zatem pełna i jednoznaczna ocena wyników szkolenia jest możliwa po uzyskaniu wyników zmiany poziomu zachowania i osiąganych rezultatów przez absolwentów kursu na stanowiskach pracy $\mathrm{w}$ organizacji delegującej. Kierujący na szkolenie powinien ocenić czy w jego następstwie nastąpił wzrost kwalifikacji oraz zmniejszyła się ilość awarii i katastrof lotniczych z powodu błędów ludzkich i niewłaściwej organizacji lotów. Informacja ta ma fundamentalne znaczenie dla kierującego na szkolenie, ale również dla instytucji szkoleniowej.

Kierujący powinien ocenić czy inwestycja w szkolenie była opłacalna oraz czy spełniła jego oczekiwania, a organizacja szkoleniowa powinna otrzymać informację zwrotną $\mathrm{w}$ jakim kierunku doskonalić proces szkolenia aby osiągać większe przyrosty wiedzy i umiejętności, a tym samym w większym stopniu spełniać oczekiwania zleceniodawcy. Tak zaplanowane i realizowane sprzężenie zwrotne pozwala na wprowadzanie poprawek do programów nauczania, weryfikację form i metod nauczania oraz zapewnia wysoką efektywność szkoleń.

\section{Literatura}

[1] Brinkerhoff, R.O., The Success Case Method, Berrett-Koehler, San Francisco 2003.

[2] Davis R. H., Yelon L., Learning System Design, McGraw-Hill Inc., New York 1974

[3] Dudycz T. Efektywność - rozważania nad istotą i pomiarem, Prace naukowe UE nr 144, Wrocław 2010.

[4] Hamblin A.C., Evaluation and Control of Training, McGraw Hill, Maidenhead 1994.

[5] Janiak.I, Badanie efektywności szkoleń pracowniczych, Prace naukowe Akademii Ekonomicznej we Wroclawiu nr 900, $2001 \mathrm{r}$.

[6] Kirkpatrick D., Ocena efektywności szkoleń, Studio Emka, Warszawa 2001.

[7] Komisja Europejska, A Practical Guide for Preparing Proposals for Expenditure Programmes, Bruksela 2001.

[8] Kunasz M. Ocena efektywności szkolenia w przedsiębiorstwie w świetle wyników badań, Materiały i Studia Uniwersytetu Warszawskiego nr 1., 2006.

[9] Lisiecka K., Kreowanie jakości-uwarunkowania, strategie, techniki, AE,

[10] Katowice 2002

[11] Lewitowicz J., Podstawy eksploatacji statków powietrznych, ITWL, Warszawa 2006.

[12] Melnarowicz W., Ocena efektywności szkolenia personelu BSP, ITWL, Warszawa 2018.

[13] Melnarowicz K . i W., Bezzałogowe statki powietrzne, ITWL, Warszawa 2017. 
Narzędzia prowadzenia badań i oceny efektywności szkolenia personelu...

Testing tools and evaluation of the efficiency of uav personnel training according...

[14] Phillips J.J., Stone R.D., 2011, Mierzenie wyników szkoleń, praktyczny przewodnik po sześciu najważniejszych wskaźnikach oceny, Oficyna Wolters Kluwer bussines, Warszawa 2000

[15] Romanowska M., Podejście systemowe w zarządzaniu, SGH, Warszawa 2004.

[16] Siedlecka U., Statystyka - elementy teorii i zadania, Akademia Ekonomiczna we Wrocławiu 1995

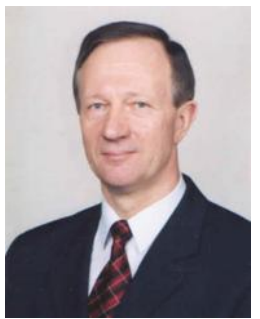

Dr in:. Wtadystaw Melnarowicz, ukończyt studia na Wydziale Mechanicznym Wojskowej Akademii Technicznej w specjalności: Samoloty i Silniki Lotnicze. Posiada 35-letni staz dydaktycznonaukowy. $W$ dydaktyce zajmowat wszystkie stanowiska od wykładowcy do komendanta szkoty lotniczej. Przeprowadzit ponad 10000 godzin zajęć dydaktycznych $z$ personelem technicznym, pilotami $i$ studentami Inżynierii Lotniczej Politechniki Wrocławskiej. Jest autorem sześciu prac badawczych, pięciu skryptów, licznych opracowań $i$ artykułów dotyczacych szkolenia personelu lotniczego oraz wspótautorem czterech koncepcji systemowych wdrożonych w kraju i za granica. Od ośmiu lat kontynuuje działalność naukowobadawcza $w$ Instytucie Technicznym Wojsk Lotniczych oraz aktywnie uczestniczy $w$ krajowych $i$ zagranicznych konferencjach, seminariach $i$ sympozjach o tematyce lotniczo-szkoleniowej. 